\title{
Quantifying the Response of an Estuarine Nekton Community to Coastal Wetland Habitat Restoration
}

\author{
Richard D. Mahoney ${ }^{1,2, *}$, Jeffrey L. Beal ${ }^{3,4}$, Dakota M. Lewis ${ }^{2,5}$ and Geoffrey S. Cook ${ }^{2}$ \\ 1 Institute of Marine Sciences, University of North Carolina, Chapel Hill, Morehead City, NC 28557, USA \\ 2 Department of Biology, University of Central Florida, Orlando, FL 32816, USA; dakotalewis@ufl.edu (D.M.L.); \\ geoffrey.cook@ucf.edu (G.S.C.) \\ 3 Ducks Unlimited Inc., Fort Pierce, FL 34946, USA; jbeal@ducks.org \\ 4 Florida Fish and Wildlife Conservation Commission, Marine and Estuarine Subsection, \\ Fort Pierce, FL 34946, USA \\ 5 School of Natural Resources and the Environment, University of Florida, Gainesville, FL 32603, USA \\ * Correspondence: rmaho448@email.unc.edu
}

Citation: Mahoney, R.D.; Beal, J.L.; Lewis, D.M.; Cook, G.S. Quantifying the Response of an Estuarine Nekton Community to Coastal Wetland Habitat Restoration. Sustainability 2021, 13, 13299. https://doi.org/ $10.3390 /$ su132313299

\section{Academic Editors:}

Giovanna McClenachan, Linda

J. Walters, Kelly M. Kibler, Lisa

G. Chambers and Timothy

L. Hawthorne

Received: 22 October 2021

Accepted: 22 November 2021

Published: 1 December 2021

Publisher's Note: MDPI stays neutral with regard to jurisdictional claims in published maps and institutional affiliations.

Copyright: (c) 2021 by the authors. Licensee MDPI, Basel, Switzerland. This article is an open access article distributed under the terms and conditions of the Creative Commons Attribution (CC BY) license (https:/ / creativecommons.org/licenses/by/ $4.0 /)$.

\begin{abstract}
Globally coastal habitats are experiencing degradation and threatening the production of critical ecosystem services such as shoreline stabilization, water filtration, and nursery grounds for marine fauna. To combat the loss of these ecosystem services, resource managers are actively restoring coastal habitats. This study compares samples collected from non-restored sites, sites restored in 2011, and sites that underwent restoration in 2019. Restoration sites are impacted wetlands with high elevation mounds that were leveled to increase the areal extent of intertidal habitats, enabling the recruitment of intertidal flora and fauna. Fyke nets were used to sample nekton within the upper intertidal zone. To quantify restoration success, nekton abundance, biomass, diversity, and indicator species were quantified. Sites restored in 2011 had a greater abundance compared to non-restored sites. Common snook, clown gobies, silversides, juvenile mullet, and Gulf killifishes were indicator species at successfully restored sites, while salinity, site type, and Secchi depth played important roles in predicting abundance and diversity. These findings are consistent with recent studies suggesting it can take years to see quantifiable differences in nekton communities following habitat restoration. Additionally, this work provides new insight regarding the benefits of restoring coastal wetland elevation to maximize intertidal habitat, thereby positively impacting nekton communities.
\end{abstract}

Keywords: coastal restoration; indicator species; community dynamics

\section{Introduction}

The human footprint has expanded rapidly over the past few centuries and, coupled with a changing climate, habitats across the world are being impacted [1]. Large tracts of land and ecosystems have been altered or lost in rainforests, temperate forests, grassy meadows, and many aquatic habitats [2-6]. Threats such as overharvesting, eutrophication, habitat destruction, pollution, and the broader effects of climate change are major contributors to the observed losses of biodiversity, ecosystems, and habitats $[7,8]$. However, one of the major challenges with habitat loss is the loss of the associated ecosystem services produced by those habitat types [9].

Ecosystem services are resources provided by natural systems that are utilized by humans. Marine systems are specifically at risk to the increasing losses of ecosystem functions and subsequent effects on ecosystem services [10,11]. Globally, human activities alter and degrade coastal habitats, threatening the production of critical ecosystem services such as shoreline stabilization, water filtration and quality, and recreational and commercial fisheries catches [4-6,12-17]. The main drivers of marine habitat degradation are both direct via coastal development and indirect via climate change, such as coastal flooding related to sea-level rise $[18,19]$. Loss of coastal habitat can reduce nursery grounds, foraging areas, 
and the carrying capacity of a system for marine fauna. As human population densities and related development continue to increase in coastal zones, habitat degradation will also continue to occur on local to global scales with many observable losses of ecosystem services $[8,9,19-21]$.

One of the most pressing concerns with the loss of coastal wetlands is the associated loss of essential fish habitat (EFH) [22]. Essential fish habitat includes any area used by fish in any part of their life cycle, including spawning, foraging, and refuge [23]. Coastal habitats support fisheries by providing EFH for many important recreational and commercial species from their earlier stages of development and throughout their life cycles [24-28]. The abundance and production of many recreationally and commercially targeted species are positively related to the level of habitat complexity (compared to bare substrates) [8,29-37]. For example, an increase of mangroves and their prop roots are shown to positively impact many fisheries compared to mudflats in the same regions. It is estimated that the mangrove habitat is utilized by roughly $80 \%$ of fish landed globally at some point in their life cycle [38,39]. Due to the degradation of coastal habitats and the potential impacts on the production of estuarine-dependent fisheries, natural resource managers are developing new strategies and policies to protect and restore these nurseries and foraging grounds [40-42].

To improve previously degraded coastal habitats, managers are looking toward habitat restoration as a strategy to move fisheries toward sustainability $[43,44]$. Restoration has been used for decades and has resulted in the regeneration of coastal habitats, leading to improved ecosystem function and increased production of ecosystem services [36,37,44-50]. Additionally, numerous factors can influence the timing and magnitude of restoration success [51]. For example, after restoring the tidal exchange to an impounded wetland, salt-tolerant plant species began to recruit to restored areas and over a period of several years many economically important species benefited with eventual increases in species richness and overall abundance [52]. Restoring the hydrology of an impacted wetland to maximize the amount of intertidal habitat has also been shown to increase fish foraging and consumption of prey when compared to feeding in subtidal habitats [53]. Both of the aforementioned studies required adequate time for the intertidal flora to recruit before the fish community responded positively to restoration. However, other restoration projects that create structure directly (e.g., oyster reefs) may benefit the fish community relatively rapidly [35].

The restoration of living shorelines, while creating structure directly, can still take years to increase nursery function for the marine faunal community, and for fisheriesimportant species to begin recruiting to coastal wetland restoration sites [35,54]. While the ecological benefits of these restoration strategies are evident over time, the process can be expensive and logistically daunting. Furthermore, the varying response time of different components of an ecosystem creates an asymmetry between the immediate costs, as well as relatively long-term and diffuse benefits of these projects [55]. Thus, protracted monitoring and a long-term view of success are required when restoring coastal wetlands, as the benefits to the nekton and benthic community may not be observed immediately, and it can be longer still before benefits accrue to higher trophic levels and eventually the human community.

Past studies have found that restoration positively impacts the vegetative community $[35,56]$, but quantifying restoration success solely on the basis of the vegetative community fails to capture responses of the broader biotic community, including fishes and mobile decapods. For example, studies suggest commercially important shrimp populations correlate with the amount of wetland available but not the depth or volume of the estuaries [57], and abundance and commercial landings of other estuarine dependent species in the eastern US and the Gulf of Mexico correlate with the ratio of marsh or wetland area/open water [58-60]. To date, some restoration studies have found increases in species richness, abundance, and consumption/feeding rates of fishes and other nekton at restored habitats $[35,52,53]$. However, other studies have found little to no response 
from fishes and other nekton to restored habitats [61,62], and hence the response of nekton to restoration remains equivocal. To address this knowledge gap, we explore here how nekton respond to the restoration of a coastal wetland by removing sediment piles along excavated canals ('dragline ditches') to maximize intertidal habitat throughout a marsh complex. More specifically, this study quantifies the response of an estuarine fish and mobile decapod community to the restoration of dragline-ditched spoil piles in coastal Florida, with an emphasis on the role of coastal wetlands as a nursery habitat for important fisheries species.

\section{Materials and Methods}

\subsection{Study Site}

Focal restoration sites are in the southern portion of the Matanzas and Halifax River estuaries, lying adjacent to Gamble Rogers Memorial State Recreation Area and North Peninsula State Park in Flagler County, FL, USA (Figure 1). Natural areas within this region have been greatly impacted by anthropogenic activities over the past century, including the creation of mosquito control structures, the hardening of shorelines with seawalls, and broader trends toward urbanization. Influenced by the great expanses of wetlands and relatively high levels of seasonal rainfall in Florida, there are high concentrations of mosquitos and midges that can pose human health risks. To address these threats to human health along the east coast of the United States, beginning in the 1920s, resource management agencies manipulated coastal marshes to reduce water depths on the marsh platforms in an attempt to control mosquito populations (i.e., many saltmarsh mosquitos require standing water to complete their early life stages).

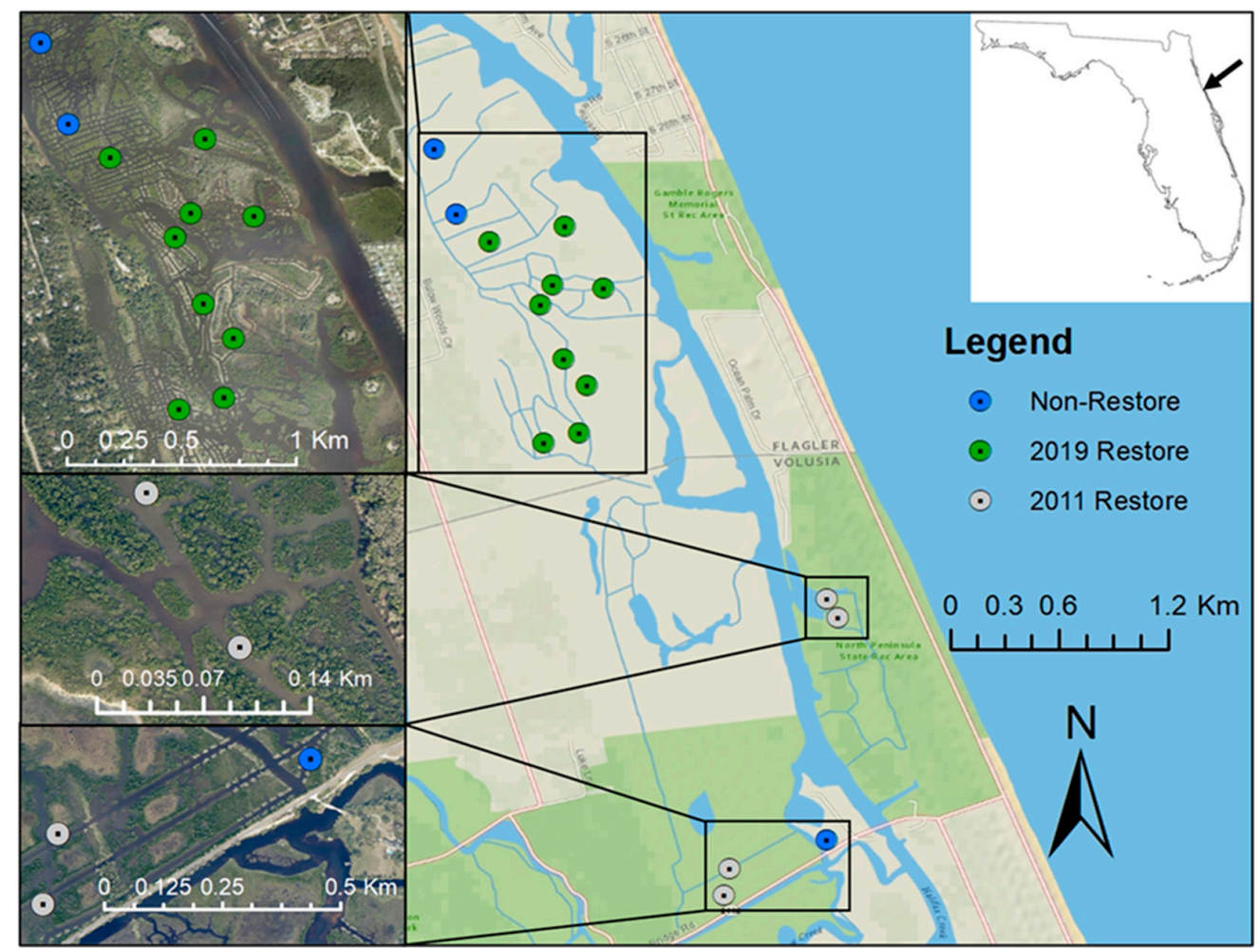

Figure 1. Map of study area in Flagler and Volusia Counties, FL, USA. Blue circles are the three sites that were not restored (Non-Restore), green circles are the nine sites restored in 2019 (2019 Restore), and the grey circles are the four sites restored in 2011 (2011 Restore). The three images on the left show the satellite view for the study areas boxed in the right image, along with the impacts of the mosquito ditching efforts to the study area. 
One strategy that managers used to control mosquito populations was to excavate draglines or "mosquito ditches" to minimize the amount of standing water on the marsh platform $[63,64]$. The construction of the draglines consisted of heavy machinery excavating canals throughout the marsh complex to facilitate draining freshwater from the marsh platform within several days of flooding $[65,66]$. When excavating the mosquito ditches, the excess sediment was piled along the shoreline, creating spoil piles. The spoil piles are at a relatively high elevation, with elevations up to one meter above mean sea level, resulting in the creation of terrestrial habitat, as opposed to intertidal habitat [67]. Upland vegetation, such as palm trees, has become established in these high elevation sites, along with invasive upland species such as Brazilian pepper (Schinus terebinthifolia) [56]. During the past two decades, the St Johns River Water Management District restored high elevation/dragline-ditch areas in northeast Florida in partnership with Florida Fish and Wildlife Conservation Commission, US Fish and Wildlife Service, Volusia County, and Florida State Parks. Spoil piles were mechanically leveled down using heavy machinery to minimize the amount of dry upland area and to maximize the area of intertidal habitat. Sites restored in this manner currently consist of predominantly native intertidal species such as black mangroves (Avicennia germinans), cord grasses (Spartina alterniflora), perennial glasswort (Sarcocornia perennis), saltwort (Batis maritima), and other intertidal flora. These restored sites were deemed a restoration success with respect to marsh flora recruitment but it is largely unknown to what extent the nekton communities in the restored areas respond to restoration.

In order to assess how nekton communities respond to spoil pile restoration, a BeforeAfter-Control-Impact (BACI) design was used. Samples were collected from 16 fixed study sites representing three treatment types: four sites previously restored in 2011 (as positive controls), three sites impacted by ditching efforts but not restored (negative controls), and nine sites restored in 2019 (Figure 1). All three treatment sites were sampled identically, but due to elevational differences associated with spoil piles, the majority of subtidal and intertidal habitat sampled at negative control sites was in the canals adjacent to spoil piles. Each monthly monitoring event consisted of 12 of the 16 fixed sites being sampled (due to ongoing restoration with heavy equipment, turbidity screens were placed across channels, making some sites inaccessible each month). The study area spans approximately $5 \mathrm{~km}$ north to south, hence north and south non-restored sites were included to mitigate potential latitudinal biases. Due to the overall size of the northern non-restored area and the southern 2011 restoration areas, they were broken into two subregions, thus allowing two monitoring sites in each. The area restored in 2019 was delineated into 15 polygons spanning the core of the study area. Each polygon contained a large area influenced by mosquito dragline-ditching, therefore having a high density of spoil piles (between 9 to 68 islands, and 48 to 114 spoil piles within each polygon). From a logistical standpoint, the polygons enabled an independent contractor to complete the mechanical restoration by working through each polygon in sequence. To identify the nine fixed monitoring sites restored in 2019, all spoil piles were numbered and a random number generator was used to select which spoil pile would be used as the fixed restore site to be monitored over the course of this study. The same technique was used to select the three non-restored sites and the four sites restored in 2011.

\subsection{Biotic Sampling Procedure}

Sampling consisted of 17 monthly three-day sampling events during the new or full moon phases, extending from March 2019 through June 2020. Fyke nets were used to sample coastal wetland nekton at each of the twelve study sites. The length of the fyke net trap mouth to the cod-end was $3.65 \mathrm{~m}$, with a mouth opening of $0.69 \times 0.99 \mathrm{~m}$ and a net mesh of $3.18 \mathrm{~mm}$. The barrier nets were a total of $9.14 \mathrm{~m}$ long, with $3 \mathrm{~m}$ of the net placed onto the marsh platform; the ends of the barrier nets were $3 \mathrm{~m}$ and $9 \mathrm{~m}$ apart. When the fyke nets were deployed, they were fished at the $3 \mathrm{~m}$ opening of the barrier nets, and the wings of the fyke net were used to close off the area and standardize the total two-dimensional 
area being fished across sites. The non-restored sites were spoil piles made up of terrestrial and intertidal habitats, so, when placing the wings of the fyke nets on them to ensure we standardized the two-dimensional area being fished, the wings would extend up onto the terrestrial area of the spoil piles. To estimate fishing effort, depth measurements within the area being fished were taken; these depth values, plus the known two-dimensional areas, were used to calculate the total three-dimensional volume of water being fished. Total water volumes were greatest at non-restored sites, followed by the sites restored in 2019, and then sites restored in 2011. Fyke nets were set at or near slack high tide and were fished for approximately five hours during the ebbing tide. As the tide ebbed, individuals using the intertidal portion of the study sites were forced towards deeper water, and, as they encountered the barrier wings, they were funneled down toward the cod-end portion of the fyke net [68].

On the afternoon of the first day of sampling, the first six sets of wings (barrier nets) were deployed at six of the twelve study sites. On day two, six fyke nets were deployed at these six sites. Following retrieval of the fyke nets, the six sets of wings were placed out to soak overnight at the remaining six study sites. On day three of each monitoring event, the next six fyke nets were deployed similarly. During fyke net retrieval, sites that had standing water were disturbed to drive organisms still inhabiting the intertidal habitat into deeper water before fyke nets wings were used to close off the area being sampled.

Large specimens were processed in the field and the remaining specimens were returned to the lab for identification to the lowest possible taxonomic level. Standard length and mass were taken for ten haphazardly selected individuals from each taxon. In addition, maximum and minimum standard lengths for each taxon, total count, and mass of all individuals for each sampling site were recorded. All biotic samples were collected and processed in accordance with the University of Central Florida Institutional Animal Care and Use Committee protocol (IACUC Permits \#16-15W and \#19-13W).

Abiotic measurements were taken at all study sites when fyke nets were deployed, including water temperature, salinity, dissolved oxygen $(\mathrm{mg} / \mathrm{L})$, and Secchi disk depth (as a proxy for water clarity/turbidity). Within the study region, there were four water quality monitoring stations run by the St Johns River Water Management District. These stations collected data on a similar suite of abiotic parameters and were used to augment point sample abiotic measurements collected during each of the three-day sampling events.

\subsection{Data Analysis}

To compare the mean differences in the fishes and mobile decapods catch rates and mean biomasses between the non-restored sites (including data collected from 2019 restored sites prior to being restored), 2019 restored sites (post-restoration), and the 2011 restored sites (post-restoration), a paired one-way analysis of variance (ANOVA) was performed. Data were assessed for normality using the Shapiro-Wilk Test $(p<0.05)$, and homogeneity of variance was tested using Levene's test $(p<0.05)$. Following a significant result of the ANOVA omnibus test, a Tukey's HSD Post Hoc test was run to identify significant differences. Abundance and biomass data were log-transformed to meet assumptions of normality. Statistical significance was set at $\alpha=0.05$ for all analyses.

Nekton community composition was analyzed using a gradient of four different biodiversity metrics calculated using the vegan package in $\mathrm{R}$ (species richness, Shannon diversity index $(\mathrm{H})$, Simpson diversity, and Pielou's evenness) [69]. Species richness was calculated as the number of species present at each site type. The Shannon diversity index takes into account abundance and richness data but weighs richness more heavily than abundance [70]. The Simpson diversity index is similar to Shannon diversity but puts more weight on abundance [71]. Pielou's evenness measures how similar species abundance is within a given sample or site [72]. Species composition data was analyzed using a Nonmetric Multidimensional Scaling (nMDS) using Bray-Curtis similarity to compare site types and sampling periods. A permutational multivariate analysis of variance (PERMANOVA) was used in conjunction with the nMDS to assess differences in species 
compositions among treatment types. To further explore what environmental drivers influenced species composition, an environmental fit test was run, where longer vectors indicate relatively greater influence [69].

The use of ecological indicators is widely used in ecology to determine the health of a system or the restoration stage of an area [73,74]. To identify potential indicator species for each of the site types, the R package, IndicSpp, was used [75]. The package determines the probability of finding a species at a particular site type (i.e., the preference for or "endemicity" of a species to a particular site type vs. other potential site types) and determines the probability of finding that species at that particular site type during a given sampling event.

Generalized linear mixed effect models (GLMs) were used to examine how restoration influences fish and mobile decapod abundance and community composition [76]. For the abundance and richness data, the dispersal statistic was used. The abundance and richness data were count data with no zeros, and the negative binomial family with a dispersal statistic of close to 1 was the best fitting family. For the community indices (evenness and Shannon and Simpson diversity), data were real numbers, so the Gaussian GLM family was used in modeling. All models had good fitting residuals. The GLMs were run with site type, temperature, DO, salinity, Secchi depth (as a metric of water clarity), distance to nearest oyster reef, moon phase, total water volume, and seasons (wet vs. dry and Spring, Summer, Winter, and Fall) as predictor variables for abundance, species richness, Shannon and Simpson diversity, and evenness using the car package in R [77]. All models were tested for collinearity using the variance inflation factor (VIF) function in the car package in R [77]. A value of 10 or greater is used to indicate if variables are collinear. Fitted models were then ranked using AICc (Akaike Information Criterion for small sample sizes) and winning models were selected based on the cut-off rule of $\triangle \mathrm{AICc} \leq 2$ [78]. If $\triangle \mathrm{AICc}$ values of multiple winning models were within 2 of one another (i.e., suggesting they have essentially the same predictive power), the most parsimonious model would be chosen as the winning model. GLMs were also run on each of the indicator species to determine which factors best predicted their abundance.

\section{Results}

A total of 28,392 specimens representing 56 unique taxa were collected over 17 sampling events spanning from March 2019 to June 2020. The three most common taxa captured were Anchoa mitchilli (bay anchovy, $\mathrm{n}=11,163$ ), Leiostomus xanthurus (spot, $\mathrm{n}=5549$ ), and Litopenaeus setiferus (Atlantic white shrimp, $\mathrm{n}=1734$ ). Bay anchovies were abundant across all treatments and time periods and comprised from $\sim 5 \%$ of the catch in February 2020 to $\sim 91 \%$ of the catch in June 2020. Spot abundance was highest in March 2019, comprising $\sim 69 \%$ of the total catch. Atlantic white shrimp abundance peaked in June 2019, making up $\sim 49 \%$ of the catch.

Mean abundances of fish were greater at sites restored in 2011 than in non-restored sites; sites restored in 2019 did not differ from the other two treatments. (Figure 2; One-way ANOVA $_{(2,200)}=3.893, p<0.05$; posthoc Tukey HSD $\left.p<0.05\right)$. Mean abundance by time suggests that prior to the 2019 restoration, the differences in the sites restored in 2011 and the non-restored sites were more prominent, with the sites restored in 2011 having elevated abundances. Prior to the 2019 restoration, the 2019 restore sites were similar to the nonrestored sites. Once the 2019 sites were restored, the catches were highly variable but mean abundances generally increased over the time post-restoration. Mean biomasses did not differ between site types (Figure 2; One-way ANOVA $F_{(2,200)}=0.174, p=0.841$ ). Six of the species captured were significantly larger than other species (Gulf and southern flounder, blue crabs, striped mullet, hardhead catfish, and Atlantic stingray), so these were removed from analyses to determine if they were potentially driving the similarity in biomasses among site types, but even with removing these species, no differences were found. Five species of sport fishes were captured during this study: common snook (Centropomus undecimalis), spotted seatrout (Cynoscion nebulosus), grey snapper (Lutjanus griseus), gulf 
flounder (Paralichthys albigutta), and southern flounder (Paralichthys lethostigma). This complex of five sport fish species had greater mean abundances at sites restored in 2011 than at other treatment types (Figure 3). Two other economically important taxa were capturedblue crabs (Callinectes sapidus) and penaeid shrimps (Litopenaeus setiferus, Atlantic white shrimp, and Farfantepenaeus spp., pink/brown shrimp). Blue crabs had greater mean abundances at sites restored in 2011 than at other treatment types, while penaeid shrimps had greater mean abundances at sites restored in 2011 and the non-restored sites, compared to the sites restored in 2019 (Figure 3).

Species richness, Shannon and Simpson diversity, and evenness were similar across all treatment types. Data were parsed into three taxonomic categories-invertebrates, fish, and fish excluding anchovies (the most numerically abundant species captured) - to determine if these specific separations had differential responses to restoration. All three taxonomic groups show no differences in these four diversity metrics. Species community analyses (nMDS and PERMANOVA) support the findings from the diversity metrics, suggesting there are no differences in the nekton community composition among treatments (at $p<0.05$, PERMANOVA pairwise tests; Figure 4). Salinity appeared to be the greatest driver of species assemblage (Figure 5).

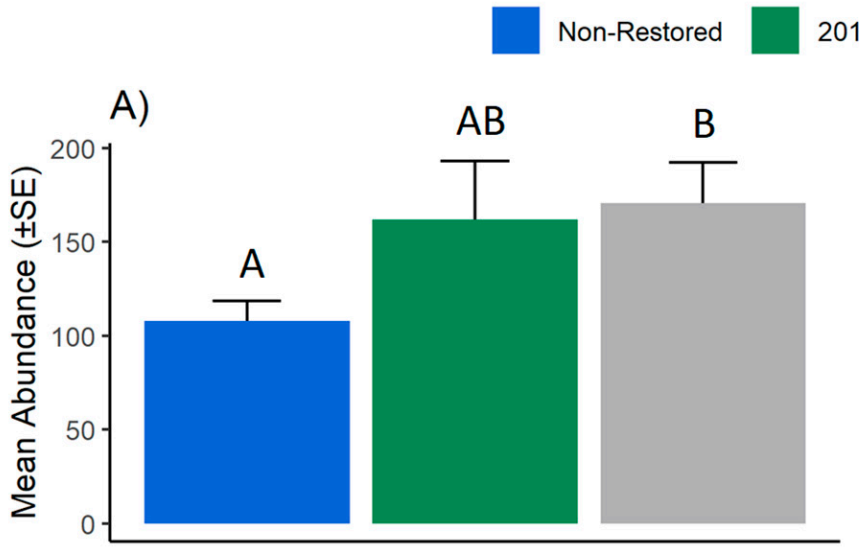

C)

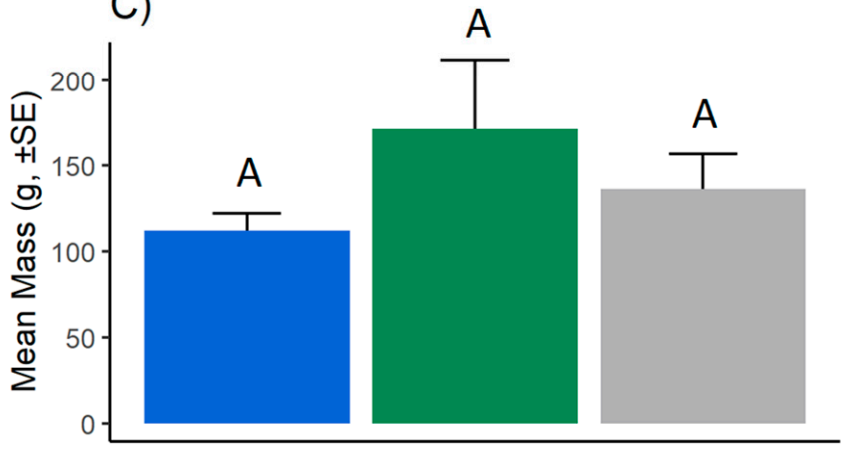

2019 Restore

B)

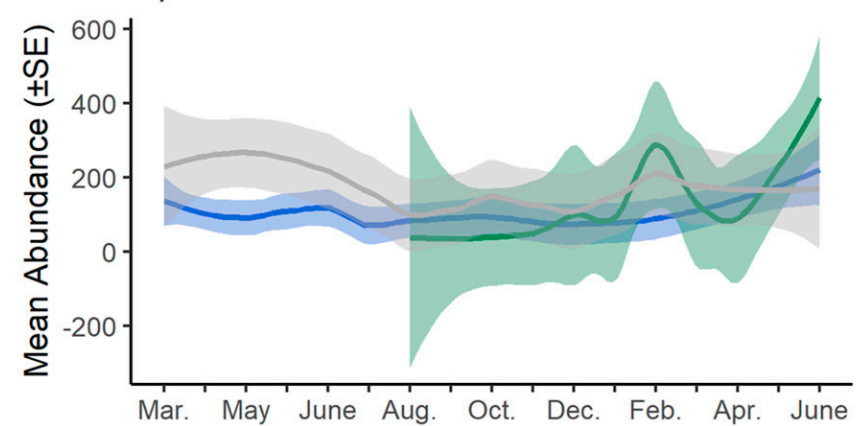

D)

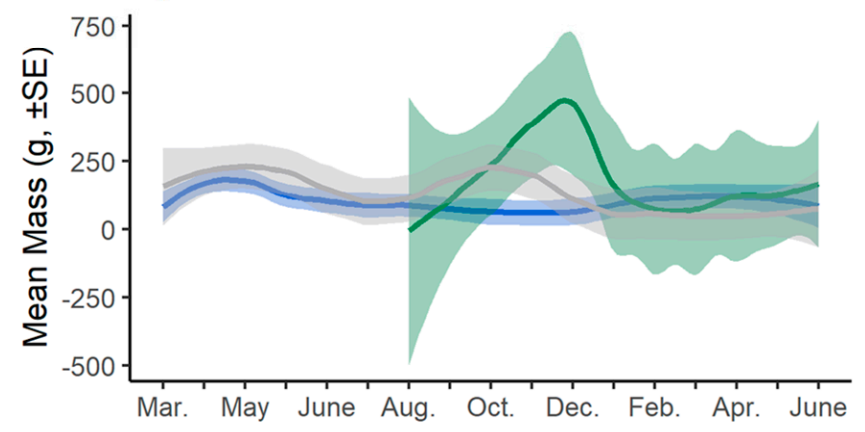

Figure 2. Mean ( \pm standard error) (A) abundance of all fishes and mobile decapods by site type; (B) abundance of all fishes and mobile decapods per sampling event for each treatment type over time (shading =95\% CI); (C) biomass of all fishes and mobile decapods by site type; and (D) biomass of all fishes and mobile decapods per sampling event for each treatment type over time (shading $=95 \% \mathrm{CI}$ ). Letters represent significant differences among treatment types, as determined by Tukey HSD post hoc tests $(p<0.05)$. 


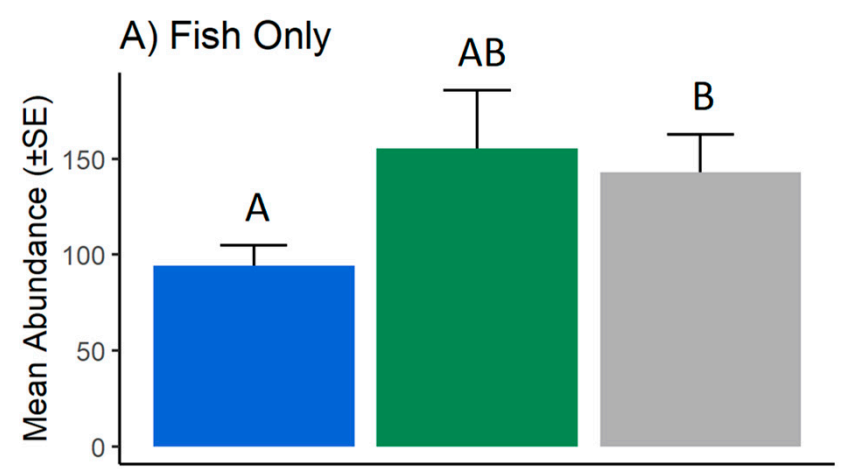

C) Blue Crabs

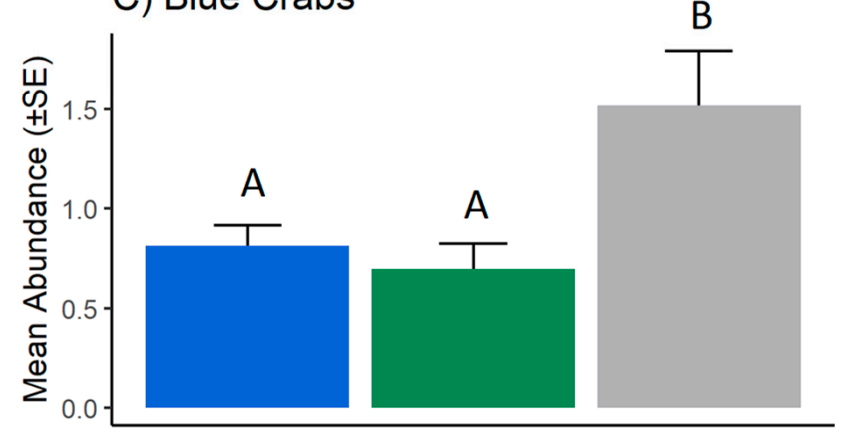

B) Sport Fish

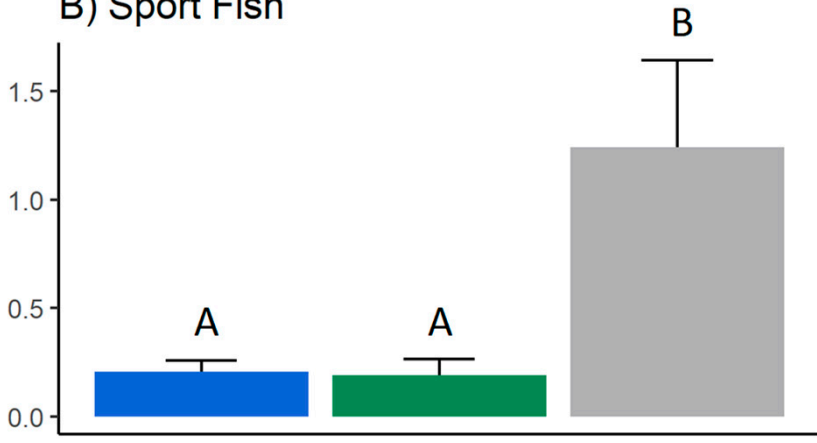

D) Penaeid Shrimps

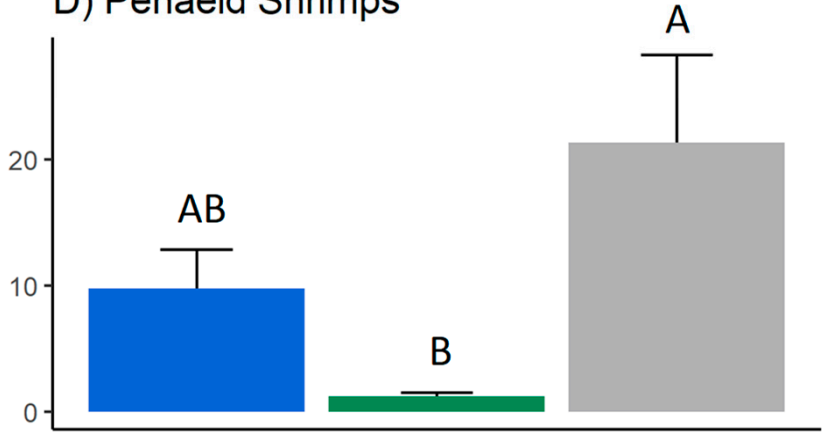

Figure 3. Mean ( \pm standard error) (A) abundance of only fishes; (B) abundance of five sport fish species captured; (C) abundance of blue crabs; and (D) abundance of penaeid shrimps by site type. Letters represent significant differences among treatment types, as determined by Tukey HSD post hoc tests $(p<0.05)$.

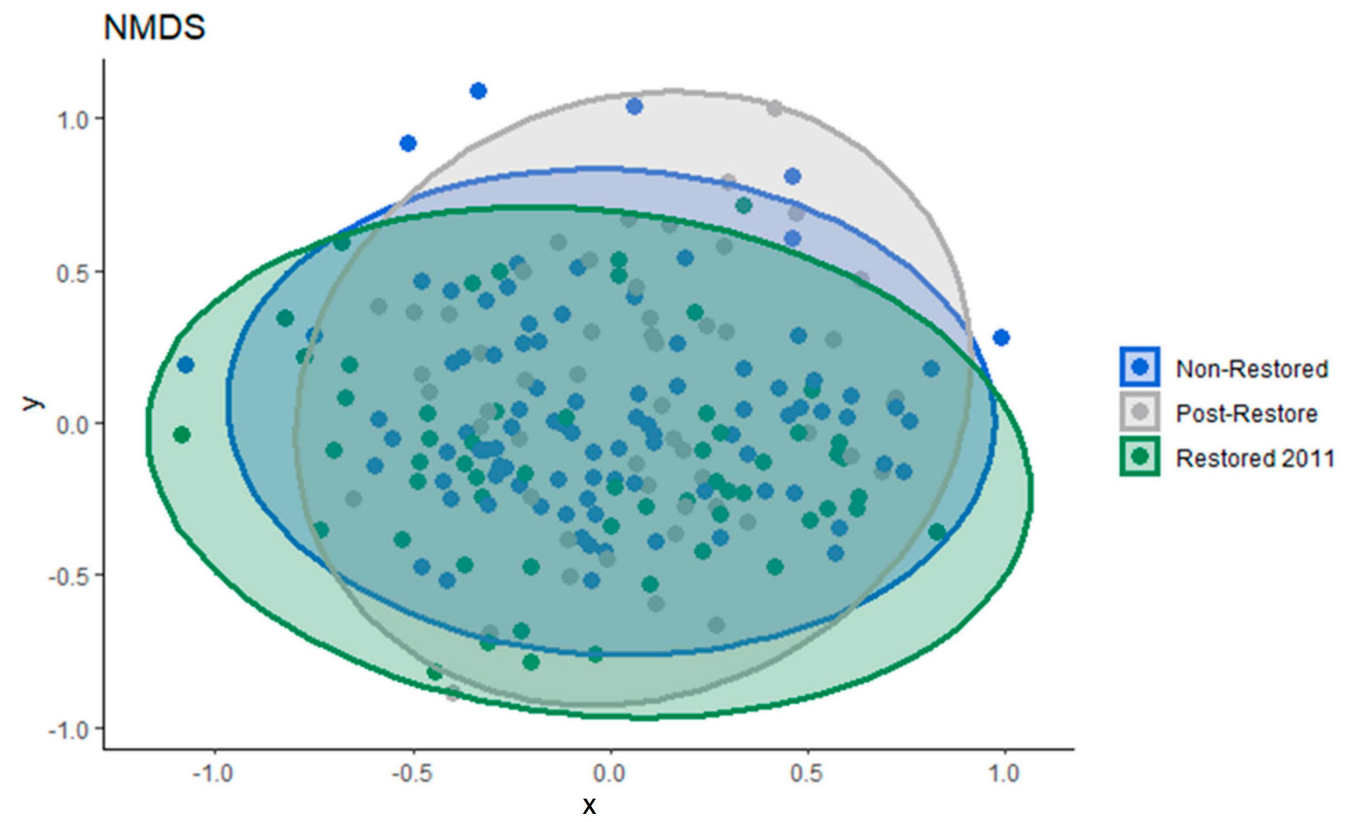

Figure 4. Comparison of species assemblages for non-restored sites (blue circle), site restored in 2011 (green circle), and sites restored in 2019 (grey circle) using nMDS, where each dot indicates a specific sample colored by site type. 


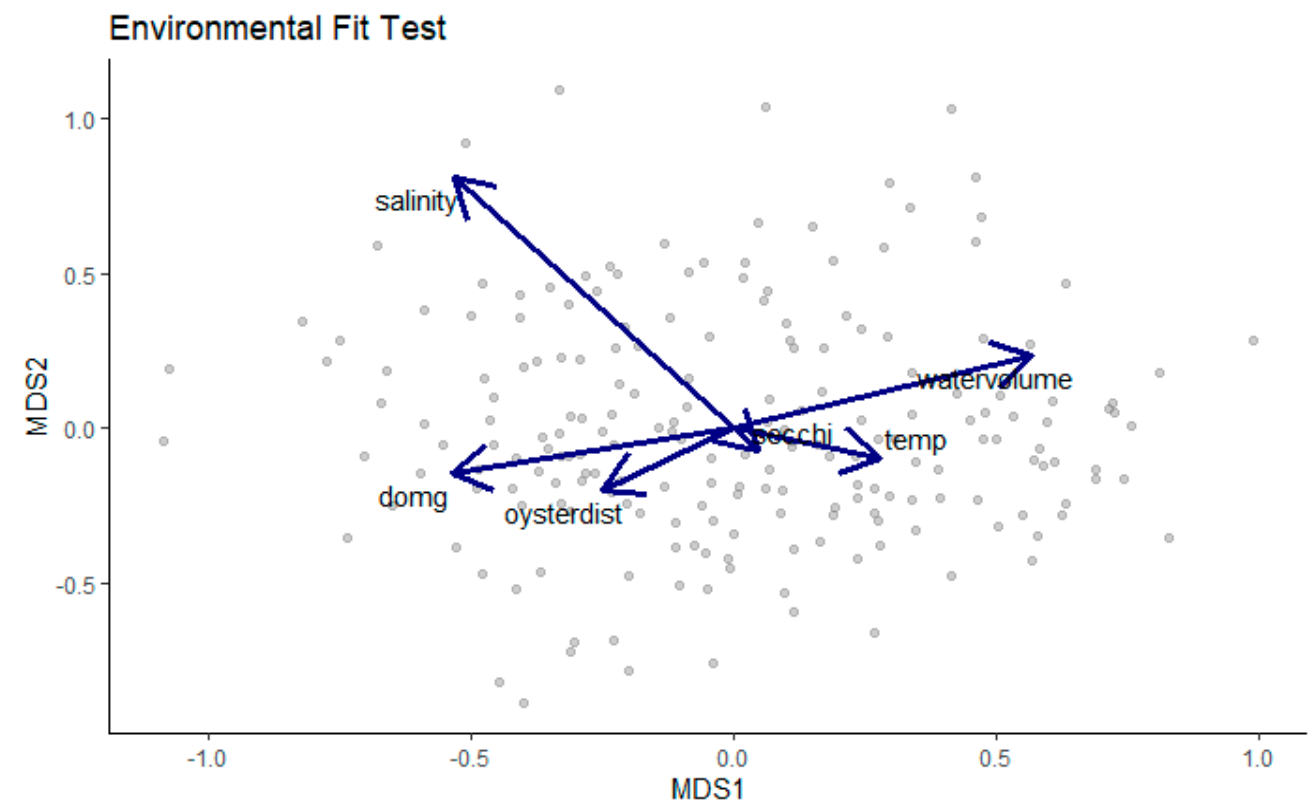

Figure 5. Environmental fit test of nMDS using mean species assemblages per treatment type. Each point represents the species assemblage of a sample. Environmental variables are in blue and the length of the vector represents the relative influence of environmental variables on species assemblage. Domg, Dissolved Oxygen; oysterdist, Distance to nearest oyster reef; watervolume, total water volume fished; temp, water temperature; Secchi, Secchi depth.

A single indicator species was identified for the sites restored in 2019, the clown goby (Microgobius gulosus) (Table 1; Figure 6; $p=0.001$ ). At sites restored in 2011, the most abundant sport fish, common snook (C. undecimalis), was identified as the indicator species (Table 1; Figure 6; $p=0.003$ ). Three ecologically important forage fish species were indicator species for both the sites restored in 2011 and the sites restored in 2019: silversides (Menidia spp.), juvenile mullet (<50 mm; Mugil spp.), and Gulf killifish (Fundulus grandis) (Table 1; Figure 7; $p=0.001, p=0.001$, and $p=0.015$ ). No indicator species were identified for the non-restored sites (Table 1).

Table 1. Indicator species by site type. Column A is indicating the probability of finding that species at that particular site type among the other site types (i.e., preference for a particular site type). Column B is indicating the probability of finding that species at that particular site type during a sampling event.

\begin{tabular}{ccccccc}
\hline Site Type & Indicator Species & $\mathbf{A}$ & $\mathbf{B}$ & Stat & $p$-Value & Total \# \\
\hline 2019 Restore & Microgobius gulosus & 0.672 & 0.642 & 0.657 & $0.001^{* * *}$ & 188 \\
\hline 2011 Restore & Centropomus undecimalis & 0.857 & 0.259 & 0.471 & $0.003^{* * *}$ & 80 \\
\hline 2019 Restore + 2011 Restore & Menidia spp. & 0.911 & 0.369 & 0.580 & $0.001^{* *}$ & 405 \\
\hline 2019 Restore + 2011 Restore & Mugil spp. & 0.927 & 0.324 & 0.548 & $0.001^{* * *}$ & 861 \\
\hline 2019 Restore + 2011 Restore & Fundulus grandis & 0.947 & 0.108 & 0.325 & $0.015^{*}$ & 48 \\
\hline
\end{tabular}

* symbol shows us the level of significance. So if a result is not significant it wouldn't have the * symbol and then when a result is significant it would have a varying level from 1 to 3 depending on the level of significance. 3 being the highest level of significance. 


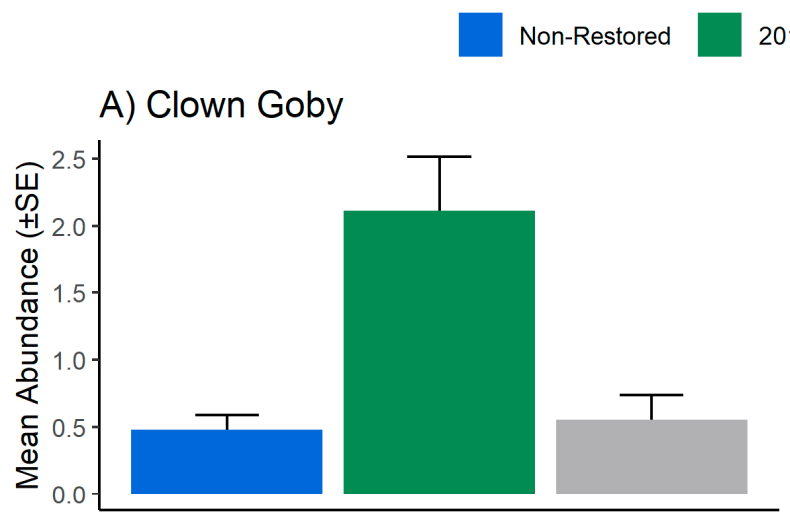

C) Common Snook

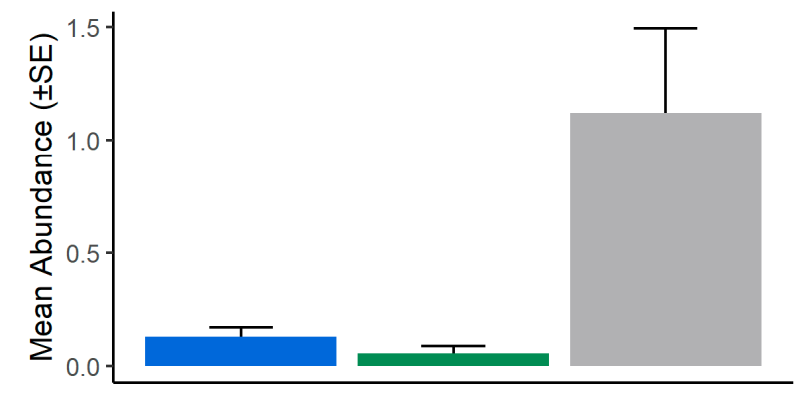

B) Clown Goby

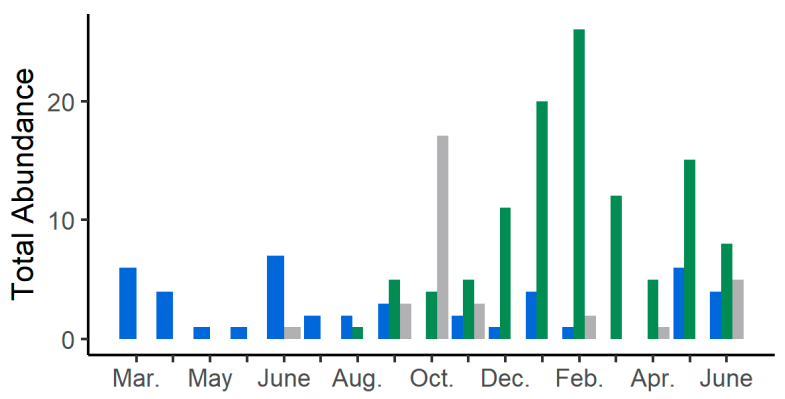

D) Common Snook

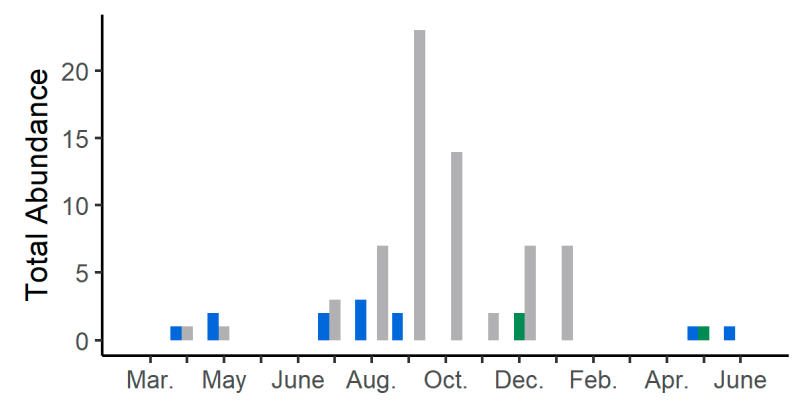

Figure 6. (A) Mean ( \pm standard error) abundance of clown gobies by site type; (B) total abundance of clown gobies per sampling event for each treatment type; (C) mean (+/ - standard error) abundance of common snook by site type; and (D) total abundance of common snook per sampling event for each treatment type.

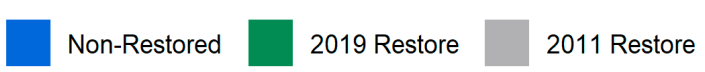

\section{A) Silversides}

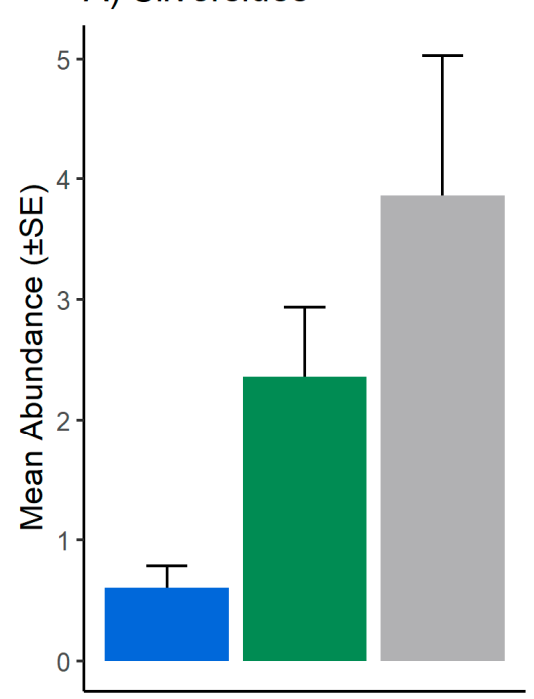

B) Juvenile Mullet

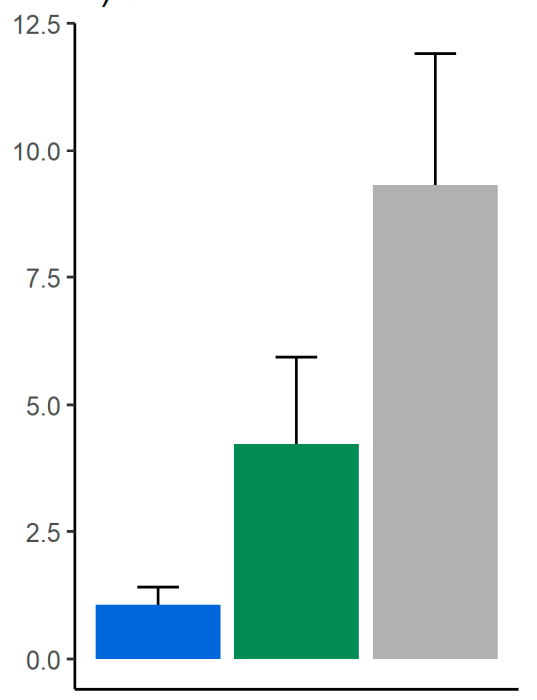

C) Gulf Killifish

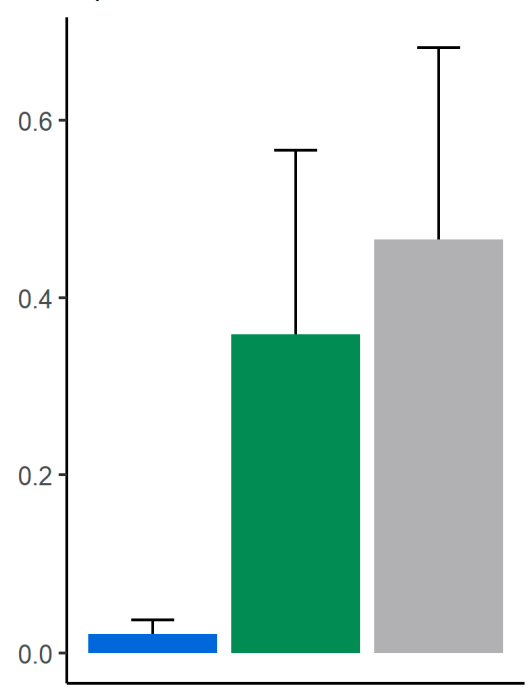

Figure 7. Mean ( \pm standard error) (A) abundance of silversides; (B) abundance of juvenile mullet; and (C) abundance of Gulf killifish by site type.

When assessing the influential environmental factors for these indicator species, GLMs were run using forward model selection. All indicator species best-fitting models included site type. The abundance of the indicator species at the 2019 restore sites (i.e., clown goby) was best predicted by the additive effects of site type, salinity, and season (i.e., Spring, Summer, Winter, and Fall) (Table 2). The abundance of the indicator species at the 2011 
Restore sites (common snook) was best predicted by the additive effects of site type, salinity, and total water volume (Table 2). The three indicator species for the sites restored in 2011 and 2019 each had different predictor variables. For the silversides, the abundance was best predicted by site type and total water volume fished. Juvenile mullet abundance was best predicted by site type, salinity, and season. Gulf killifish abundance was best predicted by site type (Table 2). However, when examining the environmental factors predicting the community composition indices, site type was less influential but was still included in the best fitting model for predicting total abundance when added with salinity (Table 3). Species richness did not have a better fitting model than the null (Table 3). For both Shannon and Simpson diversity, the best-fitting GLM included only one metric: salinity (Table 3). The best fitting GLM for the evenness included the additive effects of salinity and Secchi depth (Table 3).

Table 2. Best fit GLMs for predicting indicator species abundance.

\begin{tabular}{ccc}
\hline Indicator Species & AIC Best Model & R-Squared \\
\hline Microgobius gulosus & site type + salinity + 4 seasons & 0.207 \\
\hline Centropomus undecimalis & site type + salinity + watervolume & 0.1898 \\
\hline Menidia spp. & site type + watervolume & 0.5263 \\
\hline Mugil spp. & site type + salinity + 4 seasons & 0.7338 \\
\hline Fundulus grandis & site type & 0.1675 \\
\hline
\end{tabular}

Table 3. Best fit GLMs for predicting abundance, richness, Shannon and Simpson diversity, and evenness.

\begin{tabular}{ccc}
\hline Category & AIC Best Model & R-Squared \\
\hline Abundance & site type + salinity & 0.0768 \\
\hline Richness & null & \\
\hline Shannon Diversity & salinity & 0.0715 \\
\hline Simpson Diversity & salinity & 0.0957 \\
\hline Evenness & salinity + secchi & 0.1379 \\
\hline
\end{tabular}

\section{Discussion}

Restoration projects that modify or restore hydrology to historic specifications have resulted in positive responses by both flora and fauna $[52,79,80]$, but the impact on hydrology and response can vary by restoration type, such as reconnecting two formerly isolated water bodies or increasing the efficiency of tidal flushing. Here, the intertidal habitat area was restored by lowering the elevation of spoil piles constructed during the creation of mosquito control structures and spreading the spoil to maximize the intertidal wetland footprint. Environmental metrics throughout the study region were relatively similar, and habitat restoration had little to no effect on the abiotic conditions at each site. This is to be expected, given the relatively small spatial extent of the study region and the type of restoration carried out. However, the environmental metrics did vary seasonally and accounted for some trends in abundance and biomass of nekton. There was one environmental biotic variable that responded to habitat restoration as expected, namely, the vegetative community. The sites restored in 2011 had a high percentage coverage of intertidal flora such as black mangroves and cord grasses, as seen in other regional sites restored using this technique [56]. The aim of this restoration project was not to improve the measured water quality metrics measured (i.e., DO, salinity, turbidity, or temperature) but to create a more intertidal habitat, habitat complexity, and primary production in the form of detritus. Therefore, community composition was not expected to shift greatly but specific resident species such as killifishes, small sport-fish species, and motile decapods were hypothesized to respond to the restoration. As predicted, and in line with findings of 
previous studies, community composition was, as a whole, not altered greatly by restoration and did not differ across treatment types (Figure 4) [8]. Similarly, the largest driver of the nekton community composition in this study was salinity, but water quality parameters were not impacted by the restoration and remained similar across all treatment types (Figure 5). Another possible explanation for the community assemblages not differing among treatment types is the impact the matrix of surrounding habitat has on the treatment types and their response following restoration. In past studies, researchers have found it difficult to detect potentially subtle changes between restored versus non-restored habitats when both treatments are nested within a broader matrix comprised of other healthy or structured habitats [8]. The restoration technique used in this study involved maximizing the intertidal area with directly adjacent (within a few meters) existing intact wetland habitats. Thus, no quantifiable (statistically speaking) differences in the overall community composition compared among the different treatment types could be attributed to the restoration, having no major impacts on hydrology and the study area being relatively small and fluid in nature.

Nekton community metrics, including abundance, biomass, richness, evenness, Shannon diversity and Simpson diversity, showed varying responses to restoration and had differing drivers. Sites restored in 2011 showed elevated fish and invertebrate abundances compared to the areas not restored (Figure 2). Following restoration, the sites restored in 2019 did not differ from the sites restored in 2011 nor the non-restored sites, with respect to total fish abundance or biomass. The restoration process of physically leveling down spoil piles and creating more intertidal habitat thus did not have negative impacts on the nekton community. This suggests the trophic linkages and food web structure are functional at the sites restored in 2019. Immediately following restoration in 2019, newly restored sites had a variable but relatively limited response in nekton abundance. As mentioned above, this muted response in abundance following restoration might have been due to the natural matrix of surrounding coastal wetlands providing propagules and individuals to rapidly colonize the restored region, thereby minimizing differences among treatment types, as nekton from adjacent habitats re-colonize newly restored habitats. Restoration in this system might not have strong quantifiable impacts on the nekton community for several years but natural recruitment may result in increases in overall abundances of nekton. However, given the observed upward trend in mean abundance over time post-restoration in this study and the high relative abundances for older restored sites, this suggests that, given adequate time, the sites restored in 2019 should eventually show higher abundances than non-restored control sites as habitat complexity develops.

In the present study, water quality metrics influenced the responses in our observed community dynamics. Multiple abiotic variables influenced abundance, but two variables were common among winning models with the greatest predictive power: site type and salinity. Given that site type is the common effect for all model runs for abundance, treatment effects are important. As opposed to regions at higher latitudes, Florida has two dominant seasons that roughly correspond with the Atlantic hurricane season: wet season, May through October; and dry season, November through April [81]. Due to this, salinity was a continuous variable capturing seasonality, with the summers having the lowest salinity values due to increased rainfall and winters and dry seasons having the highest salinity. Sites restored in 2011 had elevated overall abundances across the salinity gradient relative to sites restored in 2019 and non-restored sites. In the study region, species richness was highly variable and was not well-predicted by environmental variables. However, the other three diversity metrics were strongly influenced by and had a negative relationship with salinity. Shannon and Simpson diversity metrics were best predicted by the salinity alone, whereas nekton community evenness was best predicted by the additive effects of salinity and Secchi disc depth (a proxy for water clarity). The observed negative correlation among these diversity metrics and salinity may be influenced by species recruitment increasing abundance during spring and summer months when salinity is lower. 
Contrary to the observed increases in species abundance, there were little to no differences in the overall biomasses among the different treatment types (Figure 2). Over time, it appears there were slightly elevated biomasses for restored areas, but overall, this trend was not significant. With the high variability in the size of each individual captured at the different sites, it was not possible to quantify differences in the overall biomasses among treatment types. It was thought that the larger individuals captured (such as an adult flounder, an Atlantic stingray, adult blue crabs, and adult mullet) could have influenced this finding. However, upon their removal from analyses, there was still no difference in the biomasses compared among treatment types. To investigate this further, the average body mass was calculated for each individual captured and, on average, there were smaller individuals caught at the sites restored in 2011 compared to the other treatment types. The sites restored in 2011 were also the shallowest or had the lowest total water volume fished and had higher catches compared to non-restored sites. The smaller individuals captured at the sites restored in 2011 were potentially due to the increased three-dimensional structure present from the vegetative community. This added structure possibly provided better refugia and foraging grounds for the smaller individuals that recruited to the intertidal area. In addition, the shallow depths of the restored sites generally precluded larger predators from accessing prey. A concern for resource managers regarding the non-restored habitat is that relatively deeper water enables larger predators to access nursery habitats when feeding.

In terms of taxa, some guilds appeared to have a more rapid response to restoration than others. When focusing on more economically important taxa, the five sport fish species, blue crabs, and penaeid shrimps displayed a strong response to habitat restoration, such as higher abundance at sites restored in 2011 (Figure 3). A possible reason for this is that the sites restored in 2011 have a fully recruited intertidal flora community offering both intertidal habitat and vertical structure that these species use when foraging and/or seeking refuge from predators [56]. Florida has supported valuable sport fish fisheries for decades and has been termed the "Fishing Capital of the World" because of it. This region is home to many different saltwater game species or sport fish species and the five sport fish species caught for this study contribute to Florida's USD 9.2 billion saltwater recreational fishing industry annually [82]. Furthermore, blue crabs and penaeid shrimps are large contributors to commercial landings in Florida; annually, penaeid shrimps contribute USD 48.9 million and blue crabs contribute USD 12 million to the USD 3.2 billion commercial fishing industry [83]. With the observed increases in these economically important groups in this study, this restoration project is likely increasing the carrying capacity of these species in the study area and helping move these fisheries toward sustainability.

In addition to species diversity metrics and abundances, indicator species were used to evaluate restoration success and quantify differences among site types [10,74]. One of the goals of this particular restoration effort was to promote a higher abundance of resident marsh species, such as juvenile mullet and Gulf killifish [83]. Sites restored in 2011 and 2019 had ecologically important indicator species. The clown goby was an indicator species for sites restored in 2019 (Table 1, Figure 6). These sites were characterized by shallow intertidal habitats with a relatively bare substrate. This is in line with the clown goby's life history, as they are found in higher abundance on sand or bare substrates (versus vegetated habitats); in this study, this result indicates that restoration was successful in reducing elevation below the intertidal line, thus enabling gobies to inhabit the region relatively soon after restoration. Clown gobies recruit in the winter months and, when recruiting to the study region, their preferentially inhabited sites were restored (Figure 6). Clown goby abundance appeared to be influenced by multiple environmental variables, including site type, salinity, and seasonality (Table 2). Both salinity and seasonality are reflective of clown goby abundance being highest during winter recruitment months, and site type reflects these gobies preferentially selecting shallow bare substrates following post-restoration. Whether this species is merely an early settler of a recently disturbed habitat, taking advantage of an early successional stage restored habitat, or if it will be 
replaced by superior competitors as the biogenic habitat increases complexity, requires further study. Clown gobies, juvenile mullet, Gulf killifishes, and silversides are known to be ecologically important forage fish prey of higher trophic-level species [83]. An increase in all these species at the restored areas has resulted in an overall increase in the forage fish available for the higher trophic level species to prey on. This increase in mid-trophic level fishes will hopefully support higher trophic levels and economically and ecologically important sport fish species, thereby promoting a more sustainable fishery. Further, in terms of assessing restoration success by observing increased abundances of resident marsh species and fishes at higher trophic levels, the recruitment and higher abundance of these species at restored sites suggest that the goal was achieved.

Past studies have found that nekton communities fail to respond to restoration until the vegetative community has had adequate time to establish [35,54]. In this study, the sites restored in 2011 had vegetation resembling the natural salt marshes in the broader area. Juvenile common snook recruited to these sites in large numbers and were found to be an indicator species of habitats restored in 2011 (Table 1, Figure 6). In Florida, common snook are an ecologically and economically important sport fish. Common snook are one of the top inshore sport fishes in Florida and contribute to an annual USD 9.2 billion saltwater recreational fishing industry in the State [82]. The intertidal area and increased structural complexity in this region created attractive nursery and foraging grounds for juvenile common snook. Gilmore et al. [84] found early juvenile common snook (under $100 \mathrm{~mm} \mathrm{SL}$ ) were predominantly found in freshwater and marsh habitats before moving to seagrassdominated habitats. Similarly, in this study, the majority of common snook caught at sites restored in 2011 fell into this size class. During their recruitment period (July-January), juvenile common snook were found in greater abundance at the 2011 restored sites than any other site type (Figure 6; $[56,84]$ ). Successful recruitment of common snook in the region helps protect the species from the impacts of overfishing. In 2010, the Florida common snook population was decimated by an extreme cold event that resulted in an emergency closure of the fishery [85]. The increase in preferred recruitment habitat in this study, such as that restored in 2011, is crucial to helping these fish fully recover from disturbances. Common snook prefer complex habitats such as docks, mangroves, saltmarshes, and rocky outcroppings [86]. Therefore, their proclivity for complex structure makes the presence of the common snook in restored regions an indicator of restoration success. Here, common snook abundance was influenced by multiple environmental variables, including site type, total water volume fished, and salinity (Table 2). Both the total water volume fished and site type suggest snook preferred shallower intertidal areas with increased structural complexity, and salinity illustrates that during low salinity periods or their recruitment periods, abundance was highest. However, it must also be noted that several small snook specimens were captured in newly restored sites in this study, providing further indication that restoration effects can be positive in the short term. Overall, the indicator species for this restoration span from the higher trophic levels (common snook) to the lower trophic level species (clown goby, juvenile mullet, silversides, and Gulf killifishes). Together, this suggests that the benefits of restoration occur across multiple trophic levels, illustrating the use of multiple indicator species in assessing restoration success.

\section{Conclusions}

Restoration is used increasingly as a strategy to mitigate negative anthropogenic impacts to coastal habitats by stabilizing habitats with putative benefits for the broader ecological community, including positive impacts on both the abundance and diversity of species $[43,44]$. Findings from this study suggest that restoring coastal wetlands by maximizing the area of intertidal habitats can positively impact the abundance of commercially, recreationally, and ecologically important species comprising a broader estuarine nekton community. While the response of the fish and macro-invertebrate community was not immediate, it appears that benefits to these components of the ecosystem were quantifiable within 18 months of restoration. The quality and availability of the subtidal and adjacent 
intertidal habitat greatly influence the response of the biotic community to restoration strategies, with direct impacts on restoration success. In terms of the biotic community, quantifying restoration success can be challenging and often requires several years postrestoration before significant positive impacts are realized by broader components of the system [35,54]. However, a promising finding of this study is that it provides clear evidence that restoration projects that create benthic structure, in particular by maximizing intertidal habitat, can result in relatively rapid positive responses by the biotic community when compared with restoration strategies that solely rely on natural recruitment and growth of foundation species such as oysters or mangroves [35].

Author Contributions: Conceptualization, R.D.M., J.L.B. and G.S.C.; methodology, R.D.M., J.L.B., D.M.L. and G.S.C.; formal analysis, R.D.M. and D.M.L.; investigation, R.D.M., J.L.B., D.M.L. and G.S.C.; resources, J.L.B. and G.S.C.; data curation, R.D.M. and G.S.C.; writing-original draft preparation, R.D.M.; writing—review and editing, R.D.M., J.L.B., D.M.L. and G.S.C.; visualization, R.D.M. and D.M.L.; supervision, J.L.B. and G.S.C.; project administration, J.L.B. and G.S.C.; funding acquisition, J.L.B. and G.S.C. All authors have read and agreed to the published version of the manuscript.

Funding: This research received external funding from the Florida Fish and Wildlife Conservation Commission, and D.M.L. and G.S.C. received support from the U.S. National Science Foundation, grant number CNH-1617374. Restoration was conducted in partnership with SJRWMD, FWC, and State Parks, with the National Coastal Wetlands Conservation Grant Program providing funding.

Institutional Review Board Statement: All biotic samples were collected and processed in accordance with the University of Central Florida Institutional Animal Care and Use Committee protocol (IACUC Permits \#16-15W and \#19-13W).

Data Availability Statement: Data will be made available via the UCF data repository, STARS (https:/ / stars.library.ucf.edu/, accessed on 1 November 2021), within 2 years of publication.

Acknowledgments: We thank the University of Central Florida Department of Biology for financial support in the form of a Teaching Assistantship to R.D.M. and D.M.L. Living shoreline habitat data were generated by Melinda Donnelly. The fisheries data collections would not have been feasible without the assistance of members of the Marine Ecology and Conservation Laboratory at UCF, and a multitude of community volunteers working with Florida FWC personnel.

Conflicts of Interest: The authors declare no conflict of interest.

\section{References}

1. Travis, J.M.J. Climate change and habitat destruction: A deadly anthropogenic cocktail. Proceedings of the Royal Society of London. Ser. B Biol. Sci. 2003, 270, 467-473. [CrossRef]

2. Shantz, H.L. The place of grasslands in the Earth's cover. Ecology 1954, 35, 143-145. [CrossRef]

3. Repetto, R. Deforestation in the tropics. Sci. Am. 1990, 262, 36-45. [CrossRef]

4. Beck, M.W.; Heck, K.L.; Able, K.W.; Childers, D.L.; Eggleston, D.B.; Gillanders, B.M.; Halpern, B.; Hays, C.G.; Hoshino, K.; Minello, T.J. The identification, conservation, and management of estuarine and marine nurseries for fish and invertebrates: A better understanding of the habitats that serve as nurseries for marine species and the factors that create site-specific variability in nursery quality will improve conservation and management of these areas. Bioscience 2001, 51, 633-641.

5. Able, K.W. A re-examination of fish estuarine dependence: Evidence for connectivity between estuarine and ocean habitats. Estuar. Coast. Shelf Sci. 2005, 64, 5-17. [CrossRef]

6. Li, X.; Bellerby, R.; Craft, C.; Widney, S.E. Coastal wetland loss, consequences, and challenges for restoration. Anthr. Coasts 2018, 1, 1-15. [CrossRef]

7. Grabowski, J.H.; Peterson, C.H. Restoring oyster reefs to recover ecosystem services. Ecosyst. Eng. Plants Protists 2007, 4, 281-298.

8. Brown, E.J.; Vasconcelos, R.P.; Wennhage, H.; Bergström, U.; Støttrup, J.G.; van de Wolfshaar, K.; Millisenda, G.; Colloca, F.; Le Pape, O. Conflicts in the coastal zone: Human impacts on commercially important fish species utilizing coastal habitat. ICES J. Mar. Sci. 2018, 75, 1203-1213. [CrossRef]

9. Dobson, A.; Lodge, D.; Alder, J.; Cumming, G.S.; Keymer, J.; McGlade, J.; Mooney, H.; Rusak, J.A.; Sala, O.; Wolters, V.; et al. Habitat loss, trophic collapse, and the decline of ecosystem services. Ecology 2006, 86, 1915-1924. [CrossRef]

10. Palmer, M.; Bernhardt, E.; Chornesky, E.; Collins, S.; Dobson, A.; Duke, C.; Gold, B.; Jacobson, R.; Kingsland, S.; Kranz, R.; et al. Ecology for a crowded planet. Science 2004, 304, 1251-1252. [CrossRef]

11. Worm, B.; Barbier, E.B.; Beaumont, N.; Duffy, J.E.; Folke, C.; Halpern, B.S.; Jackson, J.B.; Lotze, H.K.; Micheli, F.; Palumbi, S.R.; et al. Impacts of biodiversity loss on ocean ecosystem services. Science 2006, 314, 787-790. [CrossRef] 
12. Miller, J.M.; Reed, J.P.; Pietrafesa, L.J. Patterns, mechanisms, and approaches to the study of migrations of estuarine-dependent fish larvae and juveniles. Mech. Migr. Fishes 1984, 14, 209-225.

13. Lenihan, H.S.; Peterson, C.H. How habitat degradation through fishery disturbance enhances impacts of hypoxia on oyster reefs. Ecol. Appl. 1998, 8, 128-140. [CrossRef]

14. Sherman, K.; Duda, A.M. An ecosystem approach to global assessment and management of coastal waters. Mar. Ecol. Prog. Ser. 1999, 190, 271-287. [CrossRef]

15. Lotze, H.K.; Lenihan, H.S.; Bourque, B.J.; Bradbury, R.H.; Cooke, R.G.; Kay, M.C.; Kidwell, S.M.; Kirby, M.X.; Peterson, C.H.; Jackson, J.B. Depletion, degradation, and recovery potential of estuaries and coastal seas. Science 2006, 312, 1806-1809. [CrossRef]

16. Coen, L.D.; Brumbaugh, R.D.; Bushek, D.; Grizzle, R.; Luckenbach, M.W.; Posey, M.H.; Powers, S.P.; Tolley, S.G. Ecosystem services related to oyster restoration. Mar. Ecol. Prog. Ser. 2007, 341, 303-307. [CrossRef]

17. Holon, F.; Marre, G.; Parravicini, V.; Mouquet, N.; Bockel, T.; Descamp, P.; Tribot, A.; Boissery, P.; Deter, J. A predictive model based on multiple coastal anthropogenic pressures explains the degradation status of a marine ecosystem: Implication for management and conservation. Biol. Conserv. 2018, 222, 125-135. [CrossRef]

18. Millennium Ecosystem Assessment (MEA). Ecosystems and Human Well-Being: General Synthesis; World Resources Institute: Washington, DC, USA, 2017.

19. Lewis, D.M.; Thompson, K.A.; Macdonald, T.C.; Cook, G.S. Understanding Shifts in Estuarine Fish Communities Following Disturbances Using an Ensemble Modeling Framework. Ecol. Indic. 2021, 126, 1-14. [CrossRef]

20. Thampanya, U.; Vermaat, J.E.; Sinsakul, S.; Panapitukkul, N. Coastal erosion and mangrove progradation of Southern Thailand. Estuar. Coast. Shelf Sci. 2006, 68, 75-85. [CrossRef]

21. Cook, G.S.; Fletcher, P.J.; Kelble, C.R. Towards marine ecosystem based management in South Florida: Investigating the connections among ecosystem pressures, states, and services in a complex coastal system. Ecol. Indic. 2014, 44, 26-39. [CrossRef]

22. Rosenberg, A.; Bigford, T.E.; Leathery, S.; Hill, R.L.; Bickers, K. Ecosystem approaches to fishery management through essential fish habitat. Bull. Mar. Sci. 2000, 66, 535-542.

23. Hsu, S.L.; Wilen, J.E. Ecosystem Management and the 1996 Sustainable Fisheries Act. Ecol. Law Q. 1997, $24,799$.

24. Robertson, A.I.; Duke, N.C. Mangroves as nursery sites: Comparisons of the abundance and species composition of fish and crustaceans in mangroves and other nearshore habitats in tropical Australia. Mar. Biol. 1987, 96, 193-205. [CrossRef]

25. Primavera, J.H. Mangroves as nurseries: Shrimp populations in mangrove and non-mangrove habitats. Estuar. Coast. Shelf Sci. 1998, 46, 457-464. [CrossRef]

26. Lipcius, R.N.; Seitz, R.D.; Seebo, M.S.; Colón-Carrión, D. Density, abundance and survival of the blue crab in seagrass and unstructured salt marsh nurseries of Chesapeake Bay. J. Exp. Mar. Biol. Ecol. 2005, 319, 69-80. [CrossRef]

27. Sundblad, G.; Bergström, U. Shoreline development and degradation of coastal fish reproduction habitats. Ambio 2014, 43, 1020-1028. [CrossRef]

28. Lefcheck, J.S.; Hughes, B.B.; Johnson, A.J.; Pfirrmann, B.W.; Rasher, D.B.; Smyth, A.R.; Williams, B.L.; Beck, M.W.; Orth, R.J. Are coastal habitats important nurseries? A meta-analysis. Conserv. Lett. 2019, 12, e12645. [CrossRef]

29. Orth, R.J.; Heck, K.L.; van Montfrans, J. Faunal communities in seagrass beds: A review of the influence of plant structure and prey characteristics on predator-prey relationships. Estuaries 1984, 7, 339-350. [CrossRef]

30. Bell, J.D.; Westoby, M. Variation in seagrass height and density over a wide spatial scale: Effects on common fish and decapods. J. Exp. Mar. Biol. Ecol. 1986, 104, 275-295. [CrossRef]

31. Peterson, G.W.; Turner, R.E. The value of salt marsh edge vs interior as a habitat for fish and decapod crustaceans in a Louisiana tidal marsh. Estuaries 1994, 17, 235-262. [CrossRef]

32. Minello, T.J.; Able, K.W.; Weinstein, M.P.; Hays, C.G. Salt marshes as nurseries for nekton: Testing hypotheses on density, growth and survival through meta-analysis. Mar. Ecol. Prog. Ser. 2003, 246, 39-59. [CrossRef]

33. Grabowski, J.H.; Hughes, A.R.; Kimbro, D.L. Habitat complexity influences cascading effects of multiple predators. Ecology 2008, 89, 3413-3422. [CrossRef]

34. Stunz, G.W.; Minello, T.J.; Rozas, L.P. Relative value of oyster reef as habitat for estuarine nekton in Galveston Bay, Texas. Mar. Ecol. Prog. Ser. 2010, 406, 147-159. [CrossRef]

35. Gittman, R.K.; Peterson, C.H.; Currin, C.A.; Joel Fodrie, F.; Piehler, M.F.; Bruno, J.F. Living shorelines can enhance the nursery role of threatened estuarine habitats. Ecol. Appl. 2016, 26, 249-263. [CrossRef] [PubMed]

36. Schulz, K.; Stevens, P.W.; Hill, J.E.; Trotter, A.A.; Ritch, J.L.; Tuckett, Q.M.; Patterson, J.T. Coastal restoration evaluated using dominant habitat characteristics and associated fish communities. PLoS ONE 2020, 15, e0240623. [CrossRef]

37. Schulz, K.; Stevens, P.W.; Hill, J.E.; Trotter, A.A.; Ritch, J.L.; Williams, K.L.; Patterson, J.T.; Tuckett, Q.M. Coastal wetland restoration improves habitat for juvenile sportfish in Tampa Bay, Florida, USA. Restor. Ecol. 2020, 28, 1283-1295. [CrossRef]

38. Sullivan, C. The Importance of Mangroves. Department of planning and natural Resources, Division of Fisheries and wildlife. U.S.V.I. Fact Sheet \#28. 2005. Available online: http:/ / ufdcimages.uflib.ufl.edu/UF/00/09/34/46/00028/00028Mangroves.pdf (accessed on 1 November 2021).

39. Ellison, A.M. Managing mangroves with benthic biodiversity in mind: Moving beyond roving banditry. J. Sea Res. 2008, 59, 2-15. [CrossRef]

40. Hooke, J.M.; Bray, M.J. Coastal groups, littoral cells, policies and plans in the UK. Area 1995, 27, 358-368. 
41. Lü, Y.; Fu, B.; Feng, X.; Zeng, Y.; Liu, Y.; Chang, R.; Sun, G.; Wu, B. A policy-driven large scale ecological restoration: Quantifying ecosystem services changes in the Loess Plateau of China. PLoS ONE 2012, 7, e31782. [CrossRef]

42. Zedler, J.B.; Doherty, J.M.; Miller, N.A. Shifting restoration policy to address landscape change, novel ecosystems, and monitoring. Ecol. Soc. 2012, 17. [CrossRef]

43. Seaman, W. Artificial habitats and the restoration of degraded marine ecosystems and fisheries. Biodivers. Enclosed Seas Artif. Mar. Habitats 2007, 193, 143-155.

44. Loch, J.M.; Walters, L.J.; Cook, G.S. Recovering trophic structure through habitat restoration: A review. Food Webs 2020, 25 , e00162. [CrossRef]

45. Teas, H.J. Ecology and restoration of mangrove shorelines in Florida. Environ. Conserv. 1977, 4, 51-58. [CrossRef]

46. Broome, S.W.; Seneca, E.D.; Woodhouse, W.W., Jr. Tidal salt marsh restoration. Aquat. Bot. 1988, 32, 1-22. [CrossRef]

47. Kondolf, G.M.; Micheli, E.R. Evaluating stream restoration projects. Environ. Manag. 1995, 19, 1-15. [CrossRef]

48. Kindinger, J.; Flocks, J.; Kulp, M.; Penland, S.; Britsch, L.D.; Brewer, G.; Brooks, G.L.; Dadisman, S.; Dreher, C.; Ferina, N. Sand Resources, Regional Geology, and Coastal Processes for the Restoration of the Barataria Barrier Shoreline (No. 2001-384); US Geological Survey: Reston, VR, USA, 2001.

49. Ruiz-Jaen, M.C.; Aide, T.M. Restoration success: How is it being measured? Restor. Ecol. 2005, 13, 569-577. [CrossRef]

50. Cerco, C.F.; Noel, M.R. Can oyster restoration reverse cultural eutrophication in Chesapeake Bay? Estuaries Coasts 2007, 30, 331-343. [CrossRef]

51. Crooks, S.; Schutten, J.; Sheern, G.D.; Pye, K.; Davy, A.J. Drainage and elevation as factors in the restoration of salt marsh in Britain. Restor. Ecol. 2002, 10, 591-602. [CrossRef]

52. Brockmeyer, R.E.; Rey, J.R.; Virnstein, R.W.; Gilmore, R.G.; Earnest, L. Rehabilitation of impounded estuarine wetlands by hydrologic reconnection to the Indian River Lagoon, Florida (USA). Wetl. Ecol. Manag. 1996, 4, 93-109. [CrossRef]

53. Madon, S.P. Fish community responses to ecosystem stressors in coastal estuarine wetlands: A functional basis for wetlands management and restoration. Wetl. Ecol. Manag. 2008, 16, 219-236. [CrossRef]

54. Bayraktarov, E.; Saunders, M.I.; Abdullah, S.; Mills, M.; Beher, J.; Possingham, H.P.; Mumby, P.J.; Lovelock, C.E. The cost and feasibility of marine coastal restoration. Ecol. Appl. 2016, 26, 1055-1074. [CrossRef]

55. Cook, G.S.; Heinen, J.T. On the uncertain costs and tenuous benefits of Marine reserves: A case study of the Tortugas Ecological Reserve, South Florida, USA. Nat. Areas J. 2005, 25, 390-396.

56. Donnelly, M. Effects of Biotic Interactions on Coastal Wetland Communities with Applications for Restoration. Electronic Theses and Dissertations, University of Central Florida, Orlando, FL, USA, 2014. Showcase of Text, Archives, Research and Scholarship. Available online: https:/ / stars.library.ucf.edu/etd/4607 (accessed on 15 November 2020).

57. Turner, R.E. Intertidal vegetation and commercial yields of penaeid shrimp. Trans. Am. Fish. Soc. 1977, 106, 411-416. [CrossRef]

58. Nixon, S.W. Between coastal marshes and coastal waters-A review of twenty years of speculation and research on the role of salt marshes in estuarine productivity and water chemistry. Estuar. Wetl. Process. 1980, 11, 437-525.

59. Seaman, W. Florida Aquatic Habitat and Fishery Resources; Florida Chapter; American Fisheries Society: New York, NY, USA, 1985.

60. Zimmerman, R.J.; Minello, T.J.; Rozas, L.P. Salt marsh linkages to productivity of penaeid shrimps and blue crabs in the northern Gulf of Mexico. In Concepts and Controversies in Tidal Marsh Ecology; Springer: Dordrecht, The Netherlands, 2002 ; pp. $293-314$.

61. Rutledge, K.M.; Alphin, T.; Posey, M. Fish Utilization of Created vs. Natural Oyster Reefs (Crassostrea virginica). Estuaries Coasts 2018, 41, 2426-2432. [CrossRef]

62. Weinstein, M.P.; Hazen, R.; Litvin, S.Y. Response of Nekton to Tidal Salt Marsh Restoration, a Meta-Analysis of Restoration Trajectories. Wetlands 2019, 39, 575-585. [CrossRef]

63. Clements, B.W.; Andrew, J. Rogers. Studies of impounding for the control of salt marsh mosquitoes in Florida, 1958-1963. Mosq. News 1964, 24, 265-276.

64. Stevens, P.W.; Montague, C.L.; Sulak, K.J. Patterns of fish use and piscivore abundance within a reconnected saltmarsh impoundment in the northern Indian River Lagoon, Florida. Wetl. Ecol. Manag. 2006, 14, 147-166. [CrossRef]

65. Bertness, M.D. The Ecology of Atlantic Shorelines; Sinauer Associates: Sunderland, MA, USA, 1999; p. 417.

66. Rey, J.R.; Carlson, D.B.; Brockmeyer, R.E. Coastal wetland management in Florida: Environmental concerns and human health. Wetl. Ecol. Manag. 2012, 20, 197-211. [CrossRef]

67. Balling, S.S.; Resh, V.H. The influence of mosquito control recirculation ditches on plant biomass, production and composition in two San Francisco Bay salt marshes. Estuar. Coast. Shelf Sci. 1983, 16, 151-161. [CrossRef]

68. Neckles, H.A.; Dionne, M.; Burdick, D.M.; Roman, C.T.; Buchsbaum, R.; Hutchins, E. A monitoring protocol to assess tidal restoration of salt marshes on local and regional scales. Restor. Ecol. 2002, 10, 556-563. [CrossRef]

69. Okansen, J.; Blanchet, M.F.; Kindt, R.; Legendre, P.; Minchin, P.R.; O’Hara, R.B.; Simpson, G.L.; Solymos, P.; Stevens, M.H.H.; Wagner, H.; et al. Ecology Package "vegan". Community Ecol. Package 2018, 2, 1-295.

70. Shannon, C.E. A mathematical theory of communication. Bell Syst. Tech. J. 1948, 27, 379-423. [CrossRef]

71. Simpson, E.H. Measurement of Diversity. Nature 1949, 163, 688. [CrossRef]

72. Pielou, E.C. The measurement of diversity in different types of biological collections. J. Theor. Biol. 1966, 13, 131-144. [CrossRef]

73. Dale, V.H.; Beyeler, S.C. Challenges in the development and use of ecological indicators. Ecol. Indic. 2001, 1, 3-10. [CrossRef]

74. Gonzalez, E.; Rochefort, L.; Boudreau, S.; Hugron, S.; Poulin, M. Can indicator species predict restoration outcomes early in the monitoring process? A case study with peatlands. Ecol. Indic. 2013, 32, 232-238. [CrossRef] 
75. Cáceres, M.D.; Legendre, P. Associations between species and groups of sites: Indices and statistical inference. Ecology 2009, 90, 3566-3574. [CrossRef]

76. Zuur, A.F.; Ieno, E.N.; Walker, N.J.; Saveliev, A.A.; Smith, G.M. GLM and GAM for count data. In Mixed Effects Models and Extensions in Ecology with R; Springer: New York, NY, USA, 2009; pp. 209-243.

77. Fox, J.; Weisberg, S.; Price, B. carData: Companion to Applied Regression Data Sets (3.0-4) [Computer Software]. 2020. Available online: https: / /CRAN.R-project.org/package=carData (accessed on 1 November 2021).

78. Burnham, K.P.; Anderson, D.R. Anderson, D.R. A practical information-theoretic approach. In Model Selection and Multimodel Inference, 2nd ed.; Springer: Berlin/Heidelberg, Germany, 2002.

79. Turner, R.E.; Lewis, R.R. Hydrologic restoration of coastal wetlands. Wetl. Ecol. Manag. 1996, 4, 65-72. [CrossRef]

80. Zedler, J.B. Progress in wetland restoration ecology. Trends Ecol. Evol. 2000, 15, 402-407. [CrossRef]

81. Duever, M.J.; Meeder, J.F.; Meeder, L.C.; McCollum, J.M. The climate of south Florida and its role in shaping the everglades ecosystem. In Everglades: The Ecosystem and Its Restoration; Davis, S.M., Ogden, J.C., Eds.; St. Lucie Press: Delray Beach, FL, USA, 1994; pp. 225-248.

82. Florida Fish and Wildlife Conservation Commission. 2019. The Economic Impacts of Saltwater Fishing in Florida. Available online: myfwc.com/conservation/value/saltwater-fishing/ (accessed on 22 October 2020).

83. Gilmore, R.G.; Cooke, D.W.; Donohoe, C.J. A comparison of the fish populations and habitat in open and closed salt marsh impoundments in east-central Florida. Gulf Mexico Sci. 1982, 5, 2. [CrossRef]

84. Gilmore, R.G.; Donohoe, C.J.; Cooke, D.W. Observations on the distribution and biology of east-central Florida populations of the common snook, Centropomus undecimalis (Bloch). Florida Sci. 1983, 46, 313-336.

85. Blewett, D.A.; Stevens, P.W. Temperature variability in a subtropical estuary and implications for common snook Centropomus undecimalis, a cold-sensitive fish. Gulf Mexico Sci. 2014, 32, 4. [CrossRef]

86. Peters, K.M.; Matheson, R.E., Jr.; Taylor, R.G. Reproduction and early life history of common snook, Centropomus undecimalis (Bloch), in Florida. Bull. Mar. Sci. 1998, 62, 509-529. 